\title{
Cornual secretion on the endophallus of the honeybee drone (Apis mellifera $\mathrm{L}$ )
}

\author{
G Koeniger ${ }^{1}, \mathrm{M}$ Wissel ${ }^{1}$, W Herth ${ }^{2}$ \\ 1 Institut für Bienenkunde (Polytechnische Gesellschaft), Institut für Biochemie, \\ JW Goethe-Universität, Frankfurt, K-von-Frisch-Weg 2, D-6370 Oberursel; \\ 2 Zellenlehre, Ruprecht-Karls-Universität Heidelberg, Im Neuenheimer Feld 230, \\ $D-6900$ Heidelberg, FRG
}

(Received 3 November 1989; accepted 27 March 1990)

Summary - The orange cornual layer of the drone's endophallus is produced by gland cells in the epithelium of the cornua. The occurrence of its pigment is age-dependent as newly emerged drones have no pigmentation, and all colony drones older than $\mathbf{4} \mathrm{d}$ had orange comua during the reproductive season (May and June). The absorbancy spectrum of the pigments extracted in dioxane has maxima at $300 \mathrm{~nm}, 380 \mathrm{~nm}$ and $500 \mathrm{~nm}$. In extracts from 4-d-old drones, the amount of absorbing substances was less than in extracts from 12-d-old drones, although all types of pigments were present. The production of the pigments is related to seasonal fluctuation.

Apis mellifera / drone / endophallus / cornual secretion / pigment

\section{INTRODUCTION}

The endophallus of honeybee drones has a complex structure (fig 1). The cornua of the uneverted endophallus of sexually mature drones contains a sticky orange layer which covers the inner chitin membrane. It is present in all honeybee species studied Apis mellifera, Apis cerana, Apis florea, Apis dorsata, Apis koschevnikovi and Apis andreniformis (Koeniger, unpublished data). Neither its origin nor its components are known. During copulation, the cornua are everted and the secrete becomes the outside layer. As mating continues, it is transferred into the sting chamber of the

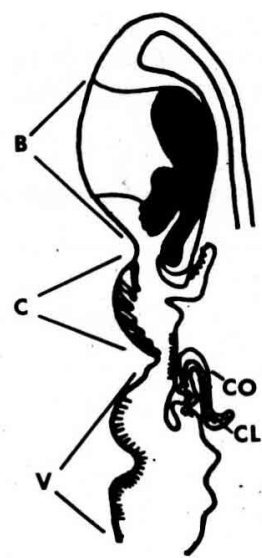

Fig 1. Uneverted endophallus. B: bulbus; C: cervix; $\mathrm{CL}$ : cornual layer; $\mathrm{CO}$ : cornu; $\mathrm{V}$ : vestibulum. 
queen. From there it adheres to the mucus and thus becomes part of the mating sign (Koeniger, 1986).

-This paper is a first step to learn more about cornual secretion. Our preliminary objective is to demonstrate the effect of age and environmental conditions on the production of the pigments. In addition, the histological origin of the cornual layer is investigated.

\section{MATERIALS AND METHODS}

To check the color of the cornua, the endophallus of each drone was everted by pressing the abdomen. In one set of experiments, the color was compared visually to the color of a sexually matured drone (older than $12 \mathrm{~d}$ ) from a colony. Three categories were distinguished: white, yellow and orange.

In another series of experiments, the relative concentration of the pigment was measured in a spectralphotometer (Beckmann 3600). The cornua were cut and the pigments extracted in $\mathbf{1 0}$ $\mathrm{ml}$ dioxane. For each series of readings, 36 drones were measured ( 8 readings). The extinction was determined at $300 \mathrm{~nm}, 380 \mathrm{~nm}$ and $500 \mathrm{~nm}$ wavelength.

Drones were examined at ages between 1 and $12 \mathrm{~d}$. For this purpose, newly emerged drones (Apis mellifera carnica) were marked. Drones were either kept in colonies or in cages. The size of the wooden cages was $5 \mathrm{~cm} \times 8 \mathrm{~cm}$ $\times 8 \mathrm{~cm}$. Within a series, each cage contained about 120 nurse bees taken from the same colony. Ten-15 newly emerged drones were added. The cages were kept in an incubator at $27^{\circ} \mathrm{C}$ and $60-70 \%$ relative humidity. Each experimental group was started with 5 cages and was provided with different diets :

- Robinia honey and pollen;

- Robinia honey only,

- sugar syrup.

Robinia honey was chosen because it contains almost no pollen (Maurizio, 1949), but provides all other elements of honey.

Because of a high death rate of drones in the first trial $(>50 \%)$, the cages were provided with empty combs in the following series. In total, 15 cages were used for each diet.

For electron microscopy, uneverted cornua from 2-day-old drones were dissected and fixed with glutaraldehyde and osmium tetroxide.

\section{RESULTS}

\section{Age related differences in pigments}

All newly emerged drones had white cornua. When they were kept in normal colonies, the color turned to yellow after 24-48 h. All drones older than $4 \mathrm{~d}$ had orange cornua during the reproductive season of the honeybee (table I).

Table I. Age-related color change of the cornua (drones in colonies).

\begin{tabular}{|c|c|c|c|c|c|}
\hline $\begin{array}{l}\text { Age of } \sigma \\
\text { (days) }\end{array}$ & White & n $\sigma^{*}$ & $\begin{array}{l}\text { with cornual color } \\
\text { Yellow }\end{array}$ & Orange & $\begin{array}{l}\text { no } \\
\text { Total }\end{array}$ \\
\hline 1 & 50 & & - & - & 50 \\
\hline 2 & 32 & & 18 & 0 & 50 \\
\hline 3 & - & & 23 & 27 & 50 \\
\hline 4 & - & & - & 50 & 50 \\
\hline
\end{tabular}




\section{Seasonal differences in pigments}

In May and June, all drones which were more than 4-d-old had orange cornua $(n=$ 50). In August, from 100 drones at the age of $6 \mathrm{~d}, 69$ drones had orange cornua, while 31 had yellow ones. This difference is significant (contingency test, $\chi^{2}=9.61$ ).

\section{Food dependent differences in pigments}

Drones were kept in cages during May and June and in no case were orange cornua developed by all drones (table II) as were seen in the colonies. This difference is significant (contingency test, $\chi^{2}=129$ ). When fed with honey and pollen, more drones had colored cornua than drones on a honey or syrup diet (test of independence in a $(R \times C)$ table, $\left.\chi^{2}=19.36\right)$. There was no difference between the diet of honey and $\operatorname{syrup}\left(\chi^{2}=1.51\right)$.

\section{Relative concentration of the pigments at different ages and diets}

The absorbancy spectrum of dioxane extracts of the cornual secretion of 12-d-old drones has maxima at wavelengths 300 $\mathrm{nm}, 380 \mathrm{~nm}$ and $500 \mathrm{~nm}$. The extinction of the dioxane extracts of the cornual secretion from drones 1 to 12-d-old was measured. It increased up to the age of $12 \mathrm{~d}$ (table III, fig 2). A clear increase in absorption was measured at $300 \mathrm{~nm}$ from drones aged between 40 and $41 \mathrm{~h}$; at $380 \mathrm{~nm}$ it started only after $\mathrm{d} 3$ and at $500 \mathrm{~nm}$ after d4. When a colony drone is 4-d-old, it has produced $57 \%$ of the substances which absorb at $300 \mathrm{~nm}$, with about $25 \%$ and $17 \%$ of the others absorbing at $380 \mathrm{~nm}$ and 500 $\mathrm{nm}$.

Extracts from 2-d-old drones kept in cages had an extinction at $300 \mathrm{~nm}$ per drone of 0.0050 , on the 3rd d, 0.0067, on

Table II. Food-related color change of the cornua (7 to 10-d-old drones, kept in cages since emergence).

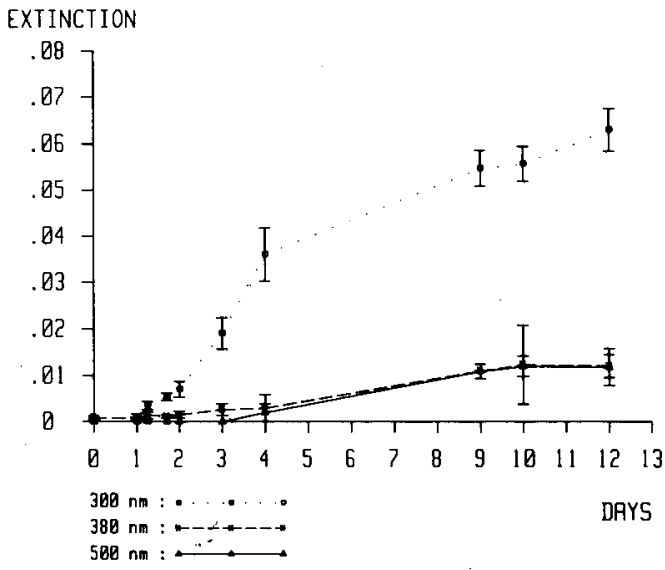

Fig 2. Extinction of dioxane extracts of drones' cornua at different ages.

\begin{tabular}{lcccc}
\hline Food & White & $\begin{array}{c}n \text { ơ with cornual color } \\
\text { Yellow }\end{array}$ & Orange & $\begin{array}{c}n \text { ơ } \\
\text { Total }\end{array}$ \\
\hline Honey + pollen & $8(8 \%)$ & $56(58 \%)$ & $33(34 \%)$ & 97 \\
Honey & $20(30 \%)$ & $38(58 \%)$ & $8(12 \%)$ & 66 \\
Syrup & $19(28 \%)$ & $35(51 \%)$ & $14(21 \%)$ & 68 \\
\hline
\end{tabular}


Table III. Extinction per drone at different ages (drones kept in colonies).

\begin{tabular}{|c|c|c|c|c|}
\hline \multirow[t]{2}{*}{ Age of } & $300 \mathrm{~nm}$ & $380 \mathrm{~nm}$ & \multicolumn{2}{|c|}{$500 \mathrm{~nm}$} \\
\hline & $E \quad S D$ & $E \quad S D$ & $E$ & $S D$ \\
\hline $0 d$ & $0.0006 \pm 0.0002$ & $0.0008 \pm 0.0006$ & - & - \\
\hline $1 d$ & $0.0010 \pm 0.0008$ & $0.0007 \pm 0.0003$ & - & - \\
\hline $1.7 \mathrm{~d}$ & $0.0054 \pm 0.0008$ & $0.0004 \pm 0.0003$ & - & - \\
\hline $2 d$ & $0.0070 \pm 0.0017$ & $0.0004 \pm 0.0003$ & - & - \\
\hline 3 & $0.0190 \pm 0.0034$ & $0.0026 \pm 0.0013$ & - & - \\
\hline & $0.0360 \pm 0.0058$ & $0.0030 \pm 0.0029$ & 0.002 & 0.0079 \\
\hline $9 d$ & $0.0547 \pm 0.0039$ & $0.0110 \pm 0.0015$ & 0.009 & 0.0015 \\
\hline $10 \mathrm{~d}$ & $0.0557 \pm 0.0038$ & $0.0123 \pm 0.0085$ & 0.012 & 0.0022 \\
\hline $12 d$ & $0.0630 \pm 0.0046$ & $0.0120 \pm 0.0025$ & 0.011 & 0.0040 \\
\hline
\end{tabular}

the 9th $d, 0.0020$ and on the 12th $d$, 0.0250 . There was no significant difference between the diets given in cages (table IV), but drones aged 9 and $12 \mathrm{~d}$ and kept in cages produced less than $40 \%$ of the amount of pigments than drones kept in colonies $(P<0.001)$.

Extracts from 5-d-old drones from $7 \mathrm{Au}$ gust had an extinction of $0.0188 \pm 0.0026$ at $300 \mathrm{~nm}$. This is significantly less than the amount of 4-d-old drones from 22 June ( $E=0.0360 \pm 0.0058 ;$-test, $P<0.001$ ).

\section{Source of secretion}

Two-d-old drones have an epithelium with secreting gland cells (fig 3 ). In the noneverted cornua, the gland cells border the hemocoel. They secrete droplets (arrows) into the chitin layers of the cornua. The droplets reach the surface of the chitin where they merge into a homogenous layer $(C L)$.

\section{DISCUSSION}

The results indicate that the sticky orange layer of the cornua is excreted by gland cells of the cornual epithelium. These gland cells have not been described before. Further investigations are needed to learn more about the activity of these cells.

The production of the secrete only starts after emergence of the drone. Since the extracts of a 1-d-old drone had shown almost no extinction while from 2-d-old

Table IV. Extinction per drone at $300 \mathrm{~nm}$ kept under different diets (drones kept in cages since emergence).

\begin{tabular}{|c|c|c|c|}
\hline Age of $\sigma^{7}$ & Honey + pollen & Honey & Sugar \\
\hline & $E \quad S D$ & $E \quad S D$ & $E \quad S D$ \\
\hline $\begin{array}{r}2 d \\
3 d \\
9 d \\
12 d\end{array}$ & $\begin{array}{l}0.0075 \pm 0.0020 \\
0.0033 \pm 0.0007 \\
0.0209 \pm 0.0030 \\
0.0320 \pm 0.0037\end{array}$ & $\begin{array}{l}0.0032 \pm 0.0018 \\
0.0027 \pm 0.0006 \\
0.0195 \pm 0.0026 \\
0.0180 \pm 0.0026\end{array}$ & $\begin{array}{l}0.0056 \pm 0.0015 \\
0.0026 \pm 0.0004 \\
0.0196 \pm 0.0050 \\
0.0240 \pm 0.0049\end{array}$ \\
\hline
\end{tabular}




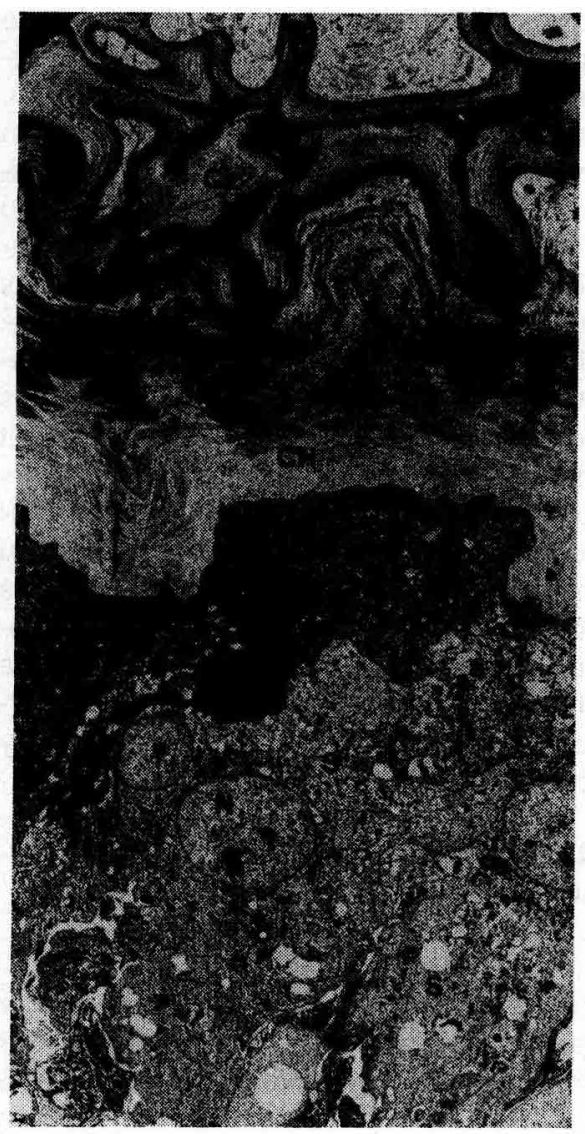

Fig 3. Cross section through the cornu. $\mathrm{CH}$ : chitin; CL: cornual layer; $\mathrm{N}$ : nucleus; $\mathrm{S}$ : secretory cells; arrows point to secretion droplets $\times 8000$.

drones the extinction was already quite high, 2 samples were collected 29-30 h and 39-40 $\mathrm{h}$ after emergence. The substances absorbing at $300 \mathrm{~nm}$ could first be determined in drones $40 \mathrm{~h}$ old. At $380 \mathrm{~nm}$, the first detection was possible on $\mathrm{d} 3$, and at $500 \mathrm{~nm}$, on $\mathrm{d} 4$.

When drones were kept in a colony during the reproductive season, they had orange cornua at the age of $4 \mathrm{~d}$. The visu- al results and the determination of the extinction at $300 \mathrm{~nm}, 380 \mathrm{~nm}$ and $500 \mathrm{~nm}$ showed that, at this age, all types of pigments were present, but the amount of absorbing substances was less than that at the age of $12 \mathrm{~d}$.

The visual color change might be related to differences in the first occurrence of extinctions at different wavelengths. However, it is not possible to relate the absorbancy spectrum directly to the reflection spectrum seen by the eye. Further, the eye can detect changes in the quality of color quite well, but not changes in pigment quantity.

In drones, there were high individual differences in the amount of pigments. As most drone samples were only collected every $24 \mathrm{~h}$, differences in age ranged from 0-24 h. This might explain part of the high variation.

Drones which emerged late in the season produced significantly less pigment than during the reproductive season. Malnutrition may be the reason for the deficient pigment secretion. In the late season, drones are not fed as well and are often hindered in honey uptake (Free, 1957; Free and Williams, 1975).

Colonies in flight rooms rear brood but, generally, they do not produce queens and drones (Velthuis, 1977). Thus, it seems likely that workers in cages do not care for drones. This may explain the fact that in all cases, caged drones produced less than half of the amount of pigments than the drones in colonies.

In the visual control, the quality of colors differed significantly between groups with and without pollen, but in all groups, some drones were able to produce yellow and orange pigments. The amount of pigment absorbed at $300 \mathrm{~nm}$ was the same in both groups. At other wavelengths, the absorption was too small to be analysed. 
Synthesis of mucus by the male accessory glands (the main substance of the mating sign) also shows a dependence on food. Caged drones produce much less mucus than drones kept under normal conditions, while sperm number and maturation is normal (Mindt, 1962). Like mucus, the synthesis of cornual pigments is dependent on external conditions.

As in the synthesis of mucus, pigment deposition appears to be related to the sexual maturation of drones. The highest level of pigment was measured at the age of $12 \mathrm{~d}$, when spermatozoa are miature (Ruttner and Tryasko, 1976) and when drones perform their first mating flight (Drescher, 1968).

\section{ACKNOWLEDGMENTS}

We thank $\mathrm{H}$ Fasold, $\mathrm{N}$ Koeniger and $\mathrm{S}$ Fuchs for many discussions. The research was supported by DFG grant Fa 48/25-1.

Résumé - Sécrétion des cornules de l'endophallus du male d'abeille (Apis mellifica $L$ ). Chez les mâles sexuellement mûrs, les cornules de l'endophallus sont recouvertes d'une couche de couleur orange (fig 1), tandis que celles des mâles récemment éclos sont blanches. A l'âge de $2 \mathrm{j}$, elles deviennent jaunes, puis oranges. A $4 \mathrm{j}$, tous les mâles ont des cornules oranges (tableau I). A la fin de la saison de reproduction, les cornules des mâles âgés de 6 j sont significativement moins oranges. II en est de même pour des mâles qui, depuis leur éclosion, ont été maintenus en cagette avec des nourrices (tableau II). On sait que, dans ces 2 cas, les mâles sont mal nourris par les ouvrières. La synthèse des pigments semble donc dépendre des soins apportés par les ouvrières aux mâles. Les pigments ont été extraits des cornules au dioxane. Le spectre d'absorption de la solution présente des maxima à 300,380 et $500 \mathrm{~nm}$. La concentration relative des pigments en fonction de l'âge des mâles a été déterminée par des mesures d'extinction (tableau III, fig 2). Tous les types de pigments semblent être présents à partir du $4^{\theta} \mathrm{j}$, mais les substances absorbantes sont en quantité bien moindres qu'à 12 j. Les mâles maintenus en cagettes ou ceux éclos en dehors de la saison de reproduction produisent moins de $50 \%$ de la quantité de pigments formés chez les mâles élevés en conditions naturelles (tableau IV). On a pu mettre en évidence dans l'épithelium des cornules, des cellules glandulaires qui secrétent des gouttelettes au niveau de la chitine. Les gouttelettes atteignent la surface de la chitine et se réunissent pour y former une couche homogène (fig 3 ).

Apis mellifica / mâle / endophallus / secrétion des cornules / pigment

Zusammenfassung - Sekretion der Hörnchen auf dem Endophallus der Drohnen der Honigbiene (Apis mellifera L). Sexuell reife Drohnen haben an den Cornua ihrer Begattungsorgane einen orangefarbigen Belag (Abb 1), während die Cornua der frisch geschlüpften Drohnen weiß sind. Im Alter von 2 Tagen werden sie zunächst gelb, danach orange. Nach 4 Tagen haben alle Drohnen orange farbene Cornua (Tabelle I). Am Ende der Paarungssaison haben 6 Tage alte Drohnen signifikant weniger orangefarbene Cornua. Das gleiche gilt für Drohnen, die vom Schlupf an mit Ammenbienen in Käfigen gehalten wurden (Tabelle II). Für beide Fälle ist bekannt, daß Arbeiterinnen unter diesen Bedingungen Drohnen normalerweise nicht aufziehen. Die Synthese der Pigmente scheint demnach von der Pflege der Drohnen durch die Arbeiterin- 
nen abhängig zu sein. Die Pigmente wurden mit Dioxan aus den Cornua extrahiert. Das Absorptionsspektrum der Lösung hat Maxima bei $300 \mathrm{~nm}, 380 \mathrm{~nm}$ und $500 \mathrm{~nm}$. Die relative Konzentration der Pigmente bei verschieden alten Drohnen konnte durch Extinktionsmessungen bestimmt werden (Tabelle III, Abb 2). Ab dem 4. Tag scheinen alle Pigmentarten vorhanden $\mathrm{zu}$ sein, aber die Menge der absorbierenden Substanzen ist wesentlich geringer als am 12. Tag. Bei Käfighaltung der Drohnen und bei Drohnen, die außerhalb der Paarungssaison geschlüpft waren, hatten die Cornua weniger als $50 \%$ der Pigmente gebildet als Drohnen unter normalen Bedingungen (Tabelle IV). Im Epithelium der Cornua konnten Drüsenzellen nachgewiesen werden, die kleine Tröpfchen in das Chitin ausscheiden. Die Tröpfchen erreichen die Oberfläche des Chitins und vereinigen sich dort $\mathrm{zu}$ einer homogenen Schicht (Abb 3).

\section{Apis mellifera / Drohne / Endophallus / Sekretion der Hörnchen / Pigment}

\section{REFERENCES}

Drescher W (1968) Die Flugaktivităt von Drohnen der Rasse Apis mellifera camica $L$ und Apis mellifera ligustica $L$ in Abhängigkeit von Lebensalter und Witterung. $Z$ Bienenforschung 9, 390-409

Free JB (1957) The food of adult drone honeybees (Apis mellifera). Brit J Anim Behav 5, 711

Free JB, Williams IH (1975) Factors determining the rearing and rejection of drones by the honeybee colony. Anim Behav 23, 650-675

Koeniger G (1986) Mating sign and multiple mating. Bee World 67, 141-150

Maurizio A (1949) Pollenanalytische Untersuchungen an Honig and Pollenhöschen. Beiheft zur Schweiz Bienenztg Band 2, 320-455

Mindt B (1962) Untersuchungen über das Leben der Drohnen, insbesondere Ernährung und Geschlechtsreife. Z Bienenforsch 6, 9-33

Ruttner F, Tryasko VV (1976) Anatomy and physiology of reproduction. In: The Instrumental Insemination of the Queen Bee (Ruttner F, ed), Apimondia, Bukarest

Velthuis HHW (1977) Population dynamic aspects and communication in a bee flight room. Insectes Soc 25, 293-296 